\title{
The Syrian Civil War: Regional Ramifications, Global Disharmony and Hegemonic Decline
}

\section{by Moritz Pieper}

\begin{abstract}
The Syrian civil war that started early in 2011 has evolved into a spiral of violence that not only has lasting consequences for the state and society of Syria, but is inevitably affecting regional power balances in the Middle Eastern and beyond. Saudi Arabia, Qatar, Iran, Russia, and Western governments are financing and supporting diametrically opposed actors in this conflict, raising the stakes and transforming what has started as a civil war into a veritable regional and international proxy war. Syrian refugees have fled to Jordan, Turkey, and Lebanon. The humanitarian catastrophe is crossing borders, rendering Syria's fate a watershed moment for the region across multiple transnational dimensions. Shedding light on these immediate regional ramifications of Syria's civil war, this article will reflect on the extent to which the Syrian civil war has become a game changer from a geopolitical perspective. Doing so, it will analyze how the war evokes fears of broader instability on a regional level, and how the conflicting power backing by influential external actors accounts for a deep-seated malaise in Great Power interactions over political conceptions not only of the geopolitical mapping of the Middle East, but of international security governance at large. It will be argued that the divergence of interests between the U.S., Russia, Turkey, Iran, Hezbollah, Saudi Arabia, and Qatar over Syria's future is indicative of a broader phenomenon of hegemonic decline and a re-balancing of power in international relations.
\end{abstract}

\section{Introduction}

The raging war in Syria is replete with examples of staggering atrocities, appalling indecision and ambiguous policy turns. The incoherent Syria policy planning of many governments is symptomatic of the perplexity with which the world watches a human tragedy unfold inexorably in Syria with its shocking long-term consequences for the Syrian people. What started as a civil uprising against an authoritarian regime in Syria in March 2011 has gradually evolved into a full-blown civil war that has spilled over into neighboring countries and has affected the stability of the entire region. The statistics of the humanitarian catastrophe are as alarming as they are numbing. Gross human rights violations and violence against the civilian population take place on a daily basis: the death toll was estimated to be around 150.000 in April 2014, tens of thousands of people are severely injured, arrested and missing, the number of refugees stands at already more than 2.7 million people, and there are an additional 6.5 million internally displaced persons. 9.5 million Syrians are in dire need of humanitarian assistance. At least 3 million children have dropped out of school as a consequence of the conflict, many are traumatized, and orphans are growing up in refugee camps in neighboring Turkey, Jordan, Lebanon, and Iraq. ${ }^{1}$ The country is in a shambles, the war damage is immense, generations lost. Amidst all this, reports of 'industrial-scale' torture of Syrian detainees and of 'barrel bomb' raids on civilian areas hit the news in mid-January $2014 .^{2}$ The

\footnotetext{
${ }^{1}$ These are official UN numbers. Estimates vary among the reporting agencies and are inherently difficult to verify on the ground.

${ }^{2}$ lan Black, "Syrian regime document trove shows evidence of 'industrial scale' killing of detainees," The Guardian, 21 January 2014. Available at: http://www.theguardian.com/world/2014/jan/20/evidence-industrialscale-killing-syria-war-crimes; "US condemns Syria regime barrel bomb raids," Al Jazeera, 5 February 2014. Available at: http://www.aljazeera.com/news/middleeast/2014/02/kerry-condemns-use-barrel-bombs-syria2014257336597576.html.
} 
so-called Geneva Communiqué of 30 June 2012 is the only basis for talks about a solution to the Syrian conflict, but peace talks so far have come to nothing because of the mutually exclusive conceptions of what a transitional government should look like. While the Syrian opposition categorically rejects the idea of Assad staying in power, the latter refuses any future participation of what he calls 'terrorists', by which he means all armed oppositional forces. Tellingly, the Geneva II talks saw an irreconcilable clash of interests, with one side focussing on the discussion of a 'transitional governing body' (TGB) and the other on the definition of 'terrorists' and the recognition of elections as the sole legitimate means to change the government composition. And at a time when Assad announced that he will run again as presidential candidate in elections to be held in June 2014, his forces are gradually gaining the upper hand militarily. As rebel forces have agreed to withdraw from Homs at the time of writing, it seems that Assad's forces are regaining the symbolic 'capital of the revolution' where the uprising started in 2011, one month before Assad's possible re-election as president. ${ }^{3}$

Such an outcome would be the result of both decisive action on the part of actors wanting his regime to stay, and of irresolute policy planning on the part of anti-Assad coalitions. The latter have allowed the de facto fragmentation of the Syrian state and an ensuing implosion of governance structures, all with detrimental consequences for regional stability. The country is already becoming a breeding ground for international terrorism, intensifying confessional tensions in the Middle East and destabilizing the entire region. Against this background, the following analysis sheds light first on the geostrategic and politico-ideological motivations and policy implications of actors in the conflict, and shows how the civil war has evolved into a contagious proxy war. The second part examines the sectarian dimensions of the conflict and shows how confessional mobilization has gone hand in hand with an increasing radicalization. On an international level, the inability of 'the international community' to respond to the Syrian imbroglio is illustrative of a process of hegemonic decline. In this context, a third part focuses on the Syria diplomacy of the principal 'Great Power' external actors, the U.S. and Russia and argue that the inability to find common approaches is indicative of a long-term process of restructuring the workings of international politics. A final part argues how the perception of Iran's role in the Syrian conflict is at the interstices of identity politics in foreign policy and paradigm changes in Middle Eastern politics.

\section{Geostrategy, Ideology, and Regional Faultlines}

Syria's civil war has quickly turned into a regional and international proxy war in which external actors are supporting various factions on the ground through different channels. This has created a dynamic in which Syria has become the epitome of politico-ideological faultlines for the Middle Eastern order.

Saudi Arabia and Qatar are financing and arming parts of the Syrian opposition, in compliance with their own regional power agenda. Already facing sectarian security challenges in Yemen, Bahrain, and Iraq, Saudi Arabia's material support for fighting groups

\footnotetext{
${ }^{3}$ Dominic Evans, "Ceasefire in Syria's Homs to allow rebel withdrawal," Reuters, 2 May 2014. Available at:
} http://uk.reuters.com/article/2014/05/02/uk-syria-crisis-homs-idUKKBNODIORF20140502. 
in Syria is motivated by a desire to change the future demographics in the region to its favor. ${ }^{4}$ Against the background of the internecine conflict between the different opposition groups and in an attempt to achieve greater cohesion among the rebels, Riyadh has therefore significantly stepped up its funding since August 2013..$^{5}$ Both Qatar and Saudi Arabia back and support factions in the civil war that are inspired by Salafist and Saudi Wahhabi branches, which arguably constitute one of the bigger threats to Western security interests. This is not to suggest that Saudi Arabia and Qatar back the same forces in Syria, however. While Qatar backs, i.a., the Free Syrian Army and the Muslim Brotherhood, Saudi Arabia has backed other elements of the Syrian opposition like the Jaish al-Islam. It has been pointed out that this rivalry of external support has in part contributed to and exacerbated the fragmentation of the Syrian opposition. ${ }^{6}$ The Qatari and Saudi Arabian divergence of interests will undoubtedly be complicated by Saudi Arabia's designation of the Muslim Brotherhood as a terrorist organization on 8 March 2014. This is a move that is also likely to impose operational constraints on the National Coalition ("of Syrian revolutionary and oppositional forces"), founded in Doha in November 2012 as the formal umbrella organization of Syrian opposition groups. ( Ironically, Qatar and Saudi Arabia have enjoyed the backing and approval of the U.S. administration in funding their proxies on the ground in Syria. American intelligence agents in Southern Turkey reportedly see to it that Saudi and Qatari weapons reach the intended, vetted parts of the opposition. ${ }^{7}$ And within Europe, France and Great Britain were the strongest advocates for the lifting of an arms embargo on Syria. With a fragmented opposition and uncontrollable supply lines on the ground in Syria, let alone the diverging funding interests between Qatar and Saudi Arabia, however, this can only be an illusory policy that produces unintended outcomes. ${ }^{8}$ Western weapon deliveries to the Syrian opposition also took place via the Jordanian-Syrian border, and parts of the moderate Syrian opposition have received military training run by the C.I.A. in Jordan.

Turkey, another direct neighbor of war-torn Syria, initially sided with Bashar al-Assad as the uprising started in March 2011. Prime Minister Erdoğan, however, soon started to shift course as it became clear that the conflict was not going to be easily contained or terminated any time soon. Ankara's foreign policy discourse increasingly became more outspoken in favor of an end to the bloodshed, until Erdoğan even questioned Assad's legitimacy as the country's ruler and publicly called on him to resign. "Assad today is not the Assad from three years ago," Erdoğan justified his stance in an interview with al-Jazeera in February 2014. ${ }^{10}$ Turkey began

\footnotetext{
${ }^{4}$ Augustus Richard Norton, "Courting Fitnah: Saudi responses to the Arab Uprisings," Visions of Gulf Security, 25 March 2014. POMEPS Studies, 41

${ }^{5}$ Yezid Sayigh, "Is the Armed Rebellion in Syria on the Wane?, Carnegie Endowment for International Peace, 24 April 2014. Available at: http://carnegie-mec.org/2014/04/24/is-armed-rebellion-in-syria-on-wane/h8z6\#.

${ }^{6}$ See Lina Khatib, "A Comprehensive Strategy for Syria: Next Steps for the West," Carnegie Policy Outlook, 4 March 2014. Available at: http://www.carnegie-mec.org/2014/03/04/comprehensive-strategy-for-syria-nextsteps-for-west/h2cb\#

${ }^{7}$ Markus Bickel, "Zögerliche Interventionisten. Das Eingreifen der Hisbollah in Syrien erhöht den Handlungsdruck des Westens," Internationale Politik, July/August 2013, 85.

${ }^{8}$ See Moritz Pieper and Octavius Pinkard, "West can ill afford to get it wrong on Syria," The Moscow Times, 13 May 2013.

${ }^{9}$ Ömer Taşpınar, "Turkey's Strategic Vision and Syria," The Washington Quarterly vol. 35: 127-140, 137.

“Erdogan: Turkey's role in the Middle East," Talk to Al Jazeera, 12 February 2014. Available at:
} 
to articulate the fear of a spill-over of the conflict onto Turkish territory and began channeling so-called 'non-lethal' (i.e. financial and limited military) support to the Syrian opposition and publicly applauded the stances Qatar and Saudi-Arabia take. ${ }^{11}$ In the context of the mounting Syrian refugee crisis, neighbouring Turkey soon became a host country for a large number of war refugees. Turkey, to date, has about 800,000 registered Syrian refugees, ${ }^{12}$ and is sure to reach a million by the end of the year. The refugee camps are overcrowded, and aid and resources are scarce. Being drawn into the Syrian tragedy through this immediate humanitarian dimension, Turkey became alarmed when the Syrian-Turkish border became the target of rocket assaults. Turkey retaliated by striking targets in Syria, ${ }^{13}$ and officially invoked Article 4 of the NATO Charter that provides for consultations among NATO member states if the security of one member is deemed to be at risk. As a reaction to the tension at the TurkishSyrian border and Turkey's increasingly assertive foreign policy rhetoric directed against Damascus, NATO then deployed Patriot Missiles in the border region and let it be known that any aggression against Turkey will be met with alliance solidarity. ${ }^{14}$ The conflict will not be allowed to spill over into Turkey, is the message. At the same time, such a decision could arguably be understood as a soothing signal to Ankara not to undertake unilateral military operations. The latter was important against the backdrop of Turkey's increasingly vocal antiAssad rhetoric. In this, Turkey is on the same page as Israel, which has even flown air attacks against targets on Syrian territory since January 2013. ${ }^{15}$

Turkey may also indirectly fear the strengthening of Kurdish independence movements. As Kurds in Northern Syria already proclaim a quasi-independent 'Western Kurdistan' in the wake of the fragmentation of governance structures there, Turkish Kurds may find renewed inspiration for irredentist claims. Tellingly, Syria's 'Party of Democratic Unity' that controls large parts in the Syrian Northeast with a large Kurdish population, has its roots in the PKK. ${ }^{16}$ Turkey's tacit allowance of jihadists to enter Syria from Eastern Anatolia - a recurring criticism brought up against Ankara - may therefore unofficially be motivated by a desire to contain Syrian Kurds.

At the same time, while Turkey and Iran were united in their public support for Bashar alAssad at the outset of the Syrian uprising in early 2011, Turkey's shifting course in the wake of the conflict has naturally also impacted and poisoned Turkish-Iranian relations. It soon became clear that Tehran and Ankara held mutually opposite ideas of the political future of Assad and Syria's future. The election of Hassan Rouhani has somewhat eased these tensions to an extent where both states were proposing a joint humanitarian aid mission in the context of the mounting Syrian refugee crisis in January 2014. Changing the fundamentals of their opposed regional agendas, however, will require much more political capital investment. Iran has maintained a strategic alliance with Syria for 30 years, and joint geostrategic

http://www.aljazeera.com/programmes/talktojazeera/2014/02/erdogan-turkey-role-middle-east201421282950445312.html

$11 \mathrm{lbid}$.

12 Syria Regional Refugee Response, Inter-agency Information Sharing Portal. Available at:

http://data.unhcr.org/syrianrefugees/country.php?id=224.

13 "Turkey strikes targets in Syria in retaliation for shelling deaths", CNN, 4 October 2012. Available at: http://edition.cnn.com/2012/10/03/world/europe/turkey-syria-tension/.

${ }^{14}$ Piotr Zalewski, "Patriot Missiles Arrive in Turkey: How They Affect the Syria Equation," Time World, 1 February 2013. Available at: http://world.time.com/2013/02/01/patriot-missiles-arrive-in-turkey-how-theyaffect-the-syria-equation/.

${ }^{15}$ BBC, "Syria conflict: Israel 'carries out Latakia air strike'," BBC, 1 November 2013. Available at: http://www.bbc.co.uk/news/world-middle-east-24767571.

${ }_{16}$ Muriel Asseburg and Heiko Wimmen, "Genf II - Chance zur Einhegung des syrischen Bürgerkriegs," SWPAktuell 3, January 2014

Field Code Changed

Field Code Changed

Field Code Changed

Field Code Changed 
considerations led to both countries joining forces in the Lebanese civil war. The founding of Hezbollah in 1982 as an Iranian-inspired militia to further Iranian interests in the Levant directly strengthened ties between Iran and Syria, as Syria was deemed a crucial corridor for the sending of weapons and other supplies from Iran to Southern Lebanon. Far from being an ideological alliance based on joint religious convictions or national interests, the SyrianIranian bond is of a purely tactical nature. Joint enemy images and similar geopolitical conceptions (resistance to Israel and the American presence in the region) have ensured that this rather paradoxical partnership has survived for so long. Syria has been called the 'golden ring of resistance against Israel' by Iranian officials like the former foreign minister Ali Akbar Velayati. ${ }^{17}$ Such a tactical partnership, however, was premised on the political stability that was ensured by the Assad regime under Hafez al-Assad and, after his death in 2000, under the leadership of Bashar al-Assad. While large parts of the Arab world supported Saddam Hussein during the Iran-Iraq war (1980-1988), Hafez al-Assad allied with Iran.

From the outbreak of the civil war in Syria, Iran thus became a natural ally of Assad's regime. "Iran will not allow the destruction of the 'Axis of resistance', whose most important column is Syria", Said Jalili, then head of the Iranian National Security Council, announced in August $2012 .{ }^{18}$ Iran is supporting the Syrian army financially and is supplying military equipment as well as intelligence. There are also reports that Iran has helped in the training and funding of a paramilitary grouping called 'al-Jaysh al-Sha'bi' (people's army), with the aim of helping the Syrian army to fight 'the rebels'. ${ }^{19}$ As well as these training activities, it is probable that the Iranian Revolutionary Guards Corps (IRGC) has a physical presence on the ground.

More than the often-mentioned tactical necessity to uphold Syria's stability to ensure a corridor to the Lebanese Hezbollah, however, Iran is motivated by its fear of the spread of Sunni extremism in the region. An implosion of the governance structures in Syria, so the reasoning goes, would result in an uncontrollable power vacuum in the country that would soon be filled by al Qaida-affiliated extremist groups that represent a direct ideological and power political threat to Shia Iran. This fear explains the official Iranian narrative of 'terrorists' infiltrating Syrian territory and seeking to overthrow the Assad regime, instigated and financed by Israel, the US and hostile Gulf states like Saudi Arabia and Qatar. This narrative fully coincides with the interpretation of adherents of the Arab-socialist Baath ideology and the somewhat fanciful 'Axis of resistance' that sees an 'American-Zionist' conspiracy at work with the aim of splitting Syrian society and causing regional havoc. Even in the hypothetical case that Supreme Leader Khamenei decided to let up on Assad, Mohsen Milani therefore argues, Iran would still support what he calls 'Assadism' - a basic preservation of systemic structures with a notable Alawite presence in the security, intelligence and armed forces, possibly in a power-sharing model with non-Jihadist elements of the opposition. ${ }^{20}$

\section{The sectarian dimension and regional complications}

The entrance of Hezbollah into the Syrian civil war in August 2013 has introduced another variable for regional complication and underlined once more the proxy dimension of this war.

\footnotetext{
${ }^{17}$ In: Karim Sadjadpour, "Verlässlicher Verbündeter. Warum Teheran das Assad-Regime auch künftig nicht fallen lassen wird, "Internationale Politik, November/December 2013, 42.

${ }^{18}$ Ibid., 43.

${ }^{19}$ Karen DeYoung and Joby Warrick, "Iran and Hezbollah build militia networks in Syria, officials say," The Guardian, 12 February 2013. Available at: http://www.theguardian.com/world/2013/feb/12/iran-hezbollahmilita-networks-syria. In this, the regime forces are also supported by the infamous Shabiha militia.

${ }^{20}$ Mohsen Milani, “Why Tehran Won't Abandon Assad(ism), " The Washington Quarterly 36, 4 (2013): 79-93, 85.
} 
Hasan Nasrallah has let it be known that Hezbollah is fighting for the survival of the Assad regime, and emphasized that his organization is ready for an 'entirely new phase' in this conflict, in which the militia will 'fight until the end'. ${ }^{21}$ Founded as an anti-Israeli militia in 1982 in the wake of the Lebanese civil war, Hezbollah regards Syria as the strategic backbone of the 'resistance' against Israel and the American presence in the region. Nasrallah has stressed that Hezbollah stands ready to defend Shia and Iranian interests even beyond Lebanon - an utterance that exemplifies the transnational dimension of Syria's civil war. And add to the cross-border dimension the sectarian implications of such statements, and it becomes clear how the Syrian conflict has triggered a dangerous dynamic of confessional dividing lines that lie at the interstices of, and overlap with national and strategic power political considerations. With Hezbollah's official entrance into this conflict, Sunni fighters and al-Qaida-affiliated extremists like Jabhat al-Nusra and the Jihadists of 'Islamic State in Iraq and al-Sham' (ISIL) ${ }^{22}$ face Shia Hezbollah combat groups that enter Syrian territory from Lebanon. The confessional divide that stirred up a spiral of violence in the aftermath of the U.S. invasion of Iraq in 2003, and continues to trouble Iraqi domestic politics until today, now officially came to coincide with combat lines between forces supporting the Assad regime and their opponents and called to mind notions of the existence of a 'Shia crescent' stretching from Tehran over Syria and parts of Iraq into the Hezbollah strongholds in Southern Lebanon. The confessional mobilization of the conflict has exacerbated confessional tensions in Iraq between the government headed by Shia Prime Minister Nuri al-Maliki and Sunni parts of the population.

And after Hezbollah fighters took back the town of al-Qusayr in the summer of 2013, Salim Idriss, then general chief of staff of the Free Syrian Army, ${ }^{23}$ threatened with retaliation and even warned to take the battle into Lebanon. ${ }^{24}$ Next to the refugee crisis in Lebanon (one out of four people in Lebanon already is a Syrian refugee), such warnings spell out the very real danger that neighbouring Lebanon is being sucked into this black hole of violence. The Bekaa valley in Lebanon has already been the target of attacks by the Syrian air force - an area that is strategically relevant for the delivery of supplies and ordnance for the Syrian opposition.

The confessional dimension of the Syrian conflict, in this regard, is thus reminiscent of the sectarian battle lines during the Lebanese civil war that raged from 1975 to 1989 and in which the sectarian violence was, just as in Syria today, additionally fuelled by external actors that

${ }^{21}$ Anne Barnard, "Hezbollah Commits to an All-Out Fight to Save Assad," The New York Times, 25 May 2013. Available at: http://www.nytimes.com/2013/05/26/world/middleeast/syrian-army-and-hezbollah-step-upraids-on-rebels.html?pagewanted=all\&_r=0.

${ }^{22}$ Suffice to note at this point that there are significant inter-factional disagreements within this 'jihadist' camp between the more aggressive ISIS and the more strategically operating al-Nusra. Notably, al-Qaida's central leadership under Ayman al-Zawahiri officially disavowed any ties with ISIS and affiliated rebel groups in Syria. See Charles Lister, "The anti-jihadist Revolt in Syria," Brookings, 19 January 2014. Available at:

http://www.brookings.edu/research/opinions/2014/01/19-anti-jihadist-revolt-syria-

lister?utm source=Facebook\&utm medium=Social\&utm campaign=BrookingsFB0121\&utm content=Brooking sFB0121\#; Ben Hubbard, "Al Qaeda Breaks With Jihadist Group in Syria Involved in Rebel Infighting," International New York Times, 3 February 2014. Available at:

http://www.nytimes.com/2014/02/04/world/middleeast/syria.html?_r=0.

${ }^{23}$ On 16 February 2014, the Free Syrian Army announced the sacking of Salam Idriss as its military chief, while several unit commanders had denounced the decision. See "Syrian opposition ends dispute over rebel chief's dismissal," Al Arabiya News, 6 March 2014. Available at: http://english.alarabiya.net/en/News/middleeast/2014/03/06/Syrian-opposition-end-dispute-over-rebel-chief-s-dismissal.html

${ }^{24}$ Shaun Waterman, "Assad forces, Hezbollah retake Qusair, head for Aleppo in Syria," The Washington Times, 5 June 2013. Available at: http://www.washingtontimes.com/news/2013/jun/5/assad-forces-hezbollah-retakequsair-head-aleppo-s/?page=all.

Field Code Changed

Field Code Changed

Field Code Changed 
were backing opposing groups and even physically intervening themselves. ${ }^{25}$ The presence of especially Syrian and Israeli forces on the ground in Lebanon and their respective backing of Palestinians and Lebanese Christians fighting each other transformed what had started as a civil war into a full-blown regional proxy war. There is a danger that the ethnic-confessional tensions that have characterised the Syrian context may spill-over into neighbouring Turkey, Lebanon, Iraq and Jordan. ${ }^{26}$

This sectarian regional power dynamic, together with the hesitance and inability of powerful international actors to respond effectively to the violence unfolding in Syria is also reminiscent of the run-up to the Bosnian war in 1995 in the wake of the implosion of former Yugoslavia, as Wolfgang Ischinger points out. Lukewarm support of the international community for parts of the opposition, attempts to mediate that come to nothing, and the inability to get the warring parties to the table and talk to each other - as much as this sounds like a description of conditions surrounding the Syrian conflict in 2013, it also perfectly applies to attempts to stop the bloodshed in the Balkans in the early 1990s. ${ }^{27}$ The Chinese and Russian vetoes in the UN Security Council give Assad a green light to continue fighting the 'rebels' and indirectly guarantee him impunity in the face of large-scale atrocities happening in Syria. Much like Slobodan Milosevic in the Bosnian context, Assad knows that he is safe as long as the international community is quarrelling over how to respond, and as long as antiAssad forces on the international level convey indecision and an unwillingness to meddle in the explosive mixture of sectarianism, regional power constellations and, as the war drags on, of radicalisation and fanaticism. As long as Assad does not have to fear a decisive international coalition ready to let action follow threats, he can rely on his military superiority and might be calculating on the military and moral exhaustion of the forces opposing his regime. This plan seems to work out perfectly, as the agreement of opposition fighters in early May 2014 to withdraw from Homs, the symbolic 'capital of the revolution', goes to show. The idea that Assad could be toppled by an armed and desperately fragmented opposition is becoming more and more illusory, as Assad's forces have made substantial gains and advances since the fall of $2013 .^{28}$ The gradual disintegration of the 'moderate' Syrian opposition, in this reasoning, is the real moral fault weighing on the conscience of those external actors calling for Assad's resignation and the struggle for a new Syria initiated by societal groups inspired by the 'Arab Spring' in the region that had started with the toppling of authoritarian rulers in Tunisia, Egypt and Libya.

The gradual confessionalisation and sectarian radicalization of the Syrian conflict has had the effect of diminishing any chances for meaningful external support for the 'moderate' forces in the Syrian opposition by now. The fear of religious radicalization as a consequence of external intervention was an argument for non-interference in Syrian domestic affairs at the outset of the civil war. Paradoxically and tragically, this argument has turned into a self-

${ }^{25}$ Fred Halliday, The Middle East in International Relations. Power, Politics and Ideology (Cambridge: Cambridge University Press, 2005), 118; Michael Jansen, The Battle of Beirut. Why Israel Invaded Lebanon (London: Zed Press, 1982); Yair Evron, War and intervention in Lebanon: The Israeli-Syrian deterrence dialogue (Beckenham: Croom Helm Ltd, 1987).

${ }^{26}$ International Crisis Group, "Syria's Metastasising Conflicts," Middle East Report 143/2013. Available at: http://www.crisisgroup.org/en/regions/middle-east-north-africa/egypt-syria-lebanon/syria/143-syriasmetastasising-conflicts.aspx.

${ }^{27}$ See Wolfgang Ischinger, "Die syrische Hölle. Warum wir die Lehren aus Bosnien nicht vergessen dürfen," Internationale Politik September/October 2013.

${ }^{28}$ Yezid Sayigh, "The Assad Regime: Winning on Points, "Carnegie Endowment for International Peace, 10 April 2014. Available at: http://carnegie-mec.org/2014/04/10/assad-regime-winning-on-points/h7vj; Yezid Sayigh, "A Melancholy Perspective on Syria," Carnegie Endowment for International Peace, 8 April 2014. Available at: http://carnegie-mec.org/2014/04/08/melancholy-perspective-on-syria/h7fc\#.

Field Code Changed

Field Code Changed 
fulfilling prophecy in that it was partially because of the lack of support or perceptible interest at the international level in finding solutions to Syria's bloodshed that has led to the increasing fragmentation of the opposition and the spread of religious extremism. Today, the argumentation for non-intervention is the same, with the difference that confessionalisation and radicalization have already taken place, ruling out military interventions for fear of causing a regional conflagration.

\section{The Syrian civil war and the international community - Global Disharmony and hegemonic decline}

The inability of the international community - however contested that term may be - to find common approaches to the war in Syria, is particularly tragic because of its immediate ramifications for the Syrian people. As a result of lukewarm declarations, empty threats and incoherent policies on the part of the international community, the war has produced a humanitarian catastrophe affecting the entire region. More than 2 million have fled Syria to seek refuge in neighboring Jordan, Turkey or Lebanon. With scarce financial resources at home, neither Lebanon nor Jordan is able to absorb the high number of Syrian refugees, let alone provide them with sufficient humanitarian aid and much-needed supplies. ${ }^{29}$ In Lebanon especially, the history and memory of large numbers of Palestinian refugees as a triggering factor for the Lebanese civil war ${ }^{30}$ makes the government wary of receiving such a high influx of refugees that complicates the already intricate social fabric of the country. International donor pledges, meanwhile, fall short of garnering the financial assistance needed to address the humanitarian crisis: Only $23 \%$ of the funding has been received that the Syria Humanitarian Assistance Response Plan (SHARP) and the Syria Regional Refugee Response Plan (RRP) schemes had pledged. ${ }^{31}$ Donor fatigue has set in, as Yezid Sayigh puts it. ${ }^{32}$

But the inability to formulate an international response to Syria's catastrophe bears witness to another development that has ramifications far beyond the region: The global disharmony is indicative of a broader phenomenon of hegemonic decline and of a re-structuring of the workings of international politics. Nothing illustrated this more clearly than the U.S.-Russian diplomatic friction over mutually opposing conceptions of Syria's future, the public trial of strength over reactions to the use of chemical weapons in August 2013 and the eventual Russian initiative to destroy Assad's chemical weapons arsenal.

When 1400 people died as a direct consequence of the use of chemical weapons in Syria on 21 August 2013, the U.S. was confronted with a dilemma it had sedulously sought to avoid. Obama's previously drawn red line had clearly been crossed. The use of chemical weapons, according to Obama's own statement exactly one year earlier, "would change my calculus. That would change my equation". ${ }^{33}$ The U.S. government, so the message went, would not

\footnotetext{
${ }^{29}$ Moritz Pieper and Octavius Pinkard, "Help those helping Syria's refugees", The Daily Star (Lebanon), 21 May 2013.

${ }^{30}$ Michael Hudson, "The Palestinian Factor in the Lebanese Civil War," The Middle East Journal 32, 3 (1978) :

261-278.

${ }^{31}$ Financial Tracking Service, "Total Funding to the Syrian Crisis 2014," Available at: http://fts.unocha.org/pageloader.aspx?page=special-syriancrisis\&year=2014.

32 Yezid Sayigh, "A Melancholy Perspective on Syria," Carnegie Endowment for International Peace, 8 April

2014. Available at: http://carnegie-mec.org/2014/04/08/melancholy-perspective-on-syria/h7fc\#.
}

${ }^{33}$ Barack Obama, "Remarks by the President to the White House Press Corps", The White House, Office of the Press Secretary, 20 August 2012. Available at: http://www.whitehouse.gov/the-press- 
rule out the use of force to respond in such an event. Israeli, Turkish, British and French government officials had already accused Damascus of the use of chemical warfare agents earlier in 2013. With the obvious and appalling use of such weapons in Syria in August 2013, then, U.S. foreign policy had to react against the background of this red line. At risk was no less than the credibility of president Obama. The hesitant decision to consider a military option, and Obama's decision to make the latter dependent on the approval of Congress, bore witness to the U.S. administration's recalcitrance and unwillingness to enter yet another military adventure in the Middle East. The U.S. invasions in Afghanistan and Iraq had cast long shadows. With Britain soon out of the game following Prime Minister Cameron's defeat in the House of Commons, only France and Turkey were uncompromisingly backing a military attack on Syria as an appropriate response. ${ }^{34}$ International approval for a U.S. attack on Syria had reached an historic low point. The destruction of Assad's chemical weapons arsenal, proposed as a solution by the Russians to dispel war speculations and made credible with Syria's ensuing ratification of the chemical weapons convention in October 2013, was thus as much a face-saving solution for the Obama administration. ${ }^{35}$ Russia had criticized what it perceived as the hastily reached conclusion that Assad was to be made responsible for the chemical weapons attack, in the absence of a 'smoking gun.' As Putin remarked, such an order from Assad was highly unlikely at a time when his forces were gaining the upper hand militarily. ${ }^{36}$ Moscow's initiative was therefore aimed at averting what was perceived as premature and dangerous playing with fire.

In explanations of Russia's stakes in the Syrian civil war, the revenues from Russian arms supplies and the naval facilities in the Syrian port of Tartus are often mentioned. Yet, leaving aside the relatively low importance of the shipyard in Tartus, ${ }^{37}$ Russia's foreign policy towards the Syrian civil war is a case in point for the implications of Russian resistance to U.S.-inspired power structures. While Western governments have become increasingly opposed to the notion of Assad staying in power, Moscow has been adamant in its support for the Assad regime for geostrategic reasons. This was illustrated not only by repeated Russian (and Chinese) vetoes in the UNSC against resolutions that could have legitimated foreign military intervention in Syria, but also by Russian deliveries of arms and military equipment. In its support for Assad, Russian and Iranian regional interests are converging, while the West and Russia have been further drifting apart. ${ }^{38}$ Like the Iranian narrative of 'terrorists' threatening to destabilize not only Syria but the entire region, Russian foreign ministry officials re-iterate that jihadists and mercenaries from the North Caucasus are moving to Syria to join forces with other Sunni extremists, threatening to destabilize not only the Middle East but also Russia's Southern borderland. ${ }^{39}$ The training and radicalization of these fighters turns

${ }^{34}$ BBC, "Syria crisis: Cameron loses Commons vote on Syria action," BBC, 30 August 2013. Available at: http://www.bbc.co.uk/news/uk-politics-23892783.

35 UNSCR 2118 stipulates the destruction of Syria's chemical weapons arsenal until mid-2014. At the time of writing, the sending of Syria's chemical weapons out of the country for eventual destruction is taking slower than expected, with only 5 percent of the arsenal sent out of the country. See Council on Foreign Relations, "Syria to Miss Chemical Weapons Deadline," Daily News Brief, 30 January 2014. Available at: http://www.cfr.org/about/newsletters/archive/newsletter/n1693?cid=soc-facebook-in-daily news briefsyria to miss chemical weapon deadline-013014.

${ }^{36}$ Reuters, "Putin says would be 'utter nonsense' for Assad to use chemical arms," Reuters, 31 August 2013. Available at: http://www.reuters.com/article/2013/08/31/us-syria-crisis-putin-idUSBRE97U06120130831. ${ }^{37}$ Roy Allison, "Russia and Syria: explaining alignment with a regime in crisis," International Affairs, 89, 4 (2013): 795-823, 807

38 Dmitri Trenin, "Russia and the West need to rediscover each other in 2013," Carnegie Endowment for International Peace, 24 December 2012. Available at http://carnegieeurope.eu/publications/?fa=50468. ${ }^{39}$ Stephan Rosiny, "Ausweg aus dem Bürgerkrieg in Syrien. Machtteilung in Syrien," Osteuropea, September 2013, 8.

Field Code Changed

Field Code Changed

Field Code Changed 
them into dangerous 'boomerang' threats for stability and societal cohesion on their return to their homes in the Caucasus and Russia. Russia characterizes the Free Syrian Army as a group of Islamists and extremists and refuses to recognize the National Coalition ("of Syrian revolutionary and oppositional forces").

"For Iran, it is an issue of regional balance of power and its own security, and for Russia it is an issue of upholding certain principles of international order and rejection of U.S. pressure", Fjodor Lukyanov reflects on this geopolitical convergence of interests between Russia and Iran over Syria. ${ }^{40}$ In both Beijing and Moscow, the memory of a Western coalition overstepping a UN mandate (UN Security Council resolution 1973) to topple Libya's Qaddafi in 2011 is still fresh. In hindsight, this resolution 1973 constituted a watershed decision for Russian policy planning: henceforth, Russian officials argue behind closed doors, Russia would no longer be deceived by a Western instrumentalization of the UN system for regime change. ${ }^{41}$

Russia's foreign policy towards the Syrian civil war is revealing a security culture that advocates resistance to power structures that have not only defined and shaped the geopolitical mapping of the Middle East, but international relations in a broader sense, as may be discerned from recent events in Crimea. In a Western reading, Russia's foreign policy is thus perceived at times as rebellious, obstinate, and disruptive at worst. The Russian vetoes against all UN Security Council resolutions on Syria have been received with frustration and bewilderment in the West.

As Dmitri Trenin argues, Putin's attempt to disperse war speculations over Syria by introducing the idea of a destruction of Assad's chemical weapons arsenal in August 2013 was meant to restore a degree of equality in U.S.-Russian relations and reassert the understanding that Russia's voice cannot be overlooked in world politics. ${ }^{42} \mathrm{~A}$ glance at a map of the Middle East, in addition, makes clear the historic significance of the Syrian war: Syria constitutes the last Russian sphere of influence in a context where the geopolitical mapping of the region is being shaken by the ramifications of the 'Arab Spring'. After regime changes in Afghanistan in 2001, in Iraq in 2003 and Libya in 2011, so goes the Russian rationale, Syria will not become another domino in a chain of U.S. foreign policy experiments - at the expense, if must be, of the suffering of the Syrian population.

The U.S.-Russian showdown over the appropriate response to developments in Syria stands exemplary for a phase of shifting centers of gravity and a process of U.S. hegemonic decline. Putin's assertive Syria policy, the Kremlin argues, made international relations more 'democratic' again. ${ }^{43}$ The understanding that the foreign policy principles of 'territorial integrity' and 'sovereignty' should govern international politics also has to be understood in this context of the idea that states should treat each other on equal terms. Tellingly, the official Russian Foreign Policy Concept breathes this ambition to 'democratise' international

${ }^{40}$ Fjodor Lukyanov, "Russia plays the Iran card," Al-monitor, 17 January 2014. Available at:

http://www.almonitor.com/pulse/originals/2014/01/geneva-ii-russia-syria-

diplomacy.html?utm source=dlvr.it\&utm medium=twitter\&goback=\%2Egde 1491617 member 5830606003 795693568\#\%21.

${ }^{41}$ See Roy Allison, "Russia and Syria: explaining alignment with a regime in crisis," International Affairs, 89, 4 (2013): 795-823, 797f.

42 Dmitri Trenin, “Putin's Syrian Game Plan,” World Today vol. 69, no. 8/9, 7 October 2013. Available at: http://www.chathamhouse.org/publications/twt/archive/view/194529.

${ }^{43}$ See Roy Allison, "Russia and Syria: explaining alignment with a regime in crisis," International Affairs, 89, 4 (2013): 795-823; Hannes Adomeit, "Fehler im Betriebssystem. Die russisch-amerikanischen Beziehungen," Osteuropa, September 2013. 
relations. ${ }^{44}$ 'Democratisation' of international relations would thus accurately characterize Russia's understanding of a desirable security culture to govern international politics. In the reading that 'democratisation' entails the deconstruction of power hierarchies, this is an explicitly counter-hegemonic endeavor.

\section{The Iran issue and regional power shifts}

Next to the U.S.-Russian divergence of interests over Syria and president Obama's foreign policy fiasco in the late summer of 2013, another permanent 'sticky issue' is the inclusion of Iran in the talks on Syria. Assad's last steadfast ally, as is slowly becoming apparent in Western capitals, needs to be at the table when options how to solve this seemingly intractable conflict are discussed. UN Secretary General Ban Ki-Moon's political faux pas and rather clumsy communication of initially inviting Iran to the Geneva-II talks and then disinviting it, ${ }^{45}$ was illustrative of the political obstacles that still prevent practical solutions that could serve as short-term confidence-building steps to bring the warring parties together notwithstanding the major contention about transfers of power to any hypothetical transitional government. ${ }^{46}$

After a largely unsuccessful first encounter in Montreux in January 2014 in the framework of the 'Geneva-II' talks, the Syrian government met with parts of the opposition in Geneva under the mediation of UN envoy Lakhdar Brahimi, who succeeded Kofi Annan as peace envoy in the summer of 2012. Yet, the crafting of any scenario for Syria is impossible without the inclusion of Iran. While the diplomatic crisis surrounding Iran's controversial nuclear program was preventing any meaningful discussions with Tehran on matters of regional stability, the Iranian diplomatic outreach following Hassan Rouhani's election in June 2013 and a first nuclear interim deal struck in Geneva on 24 November 2013 allowed for some guarded optimism. U.S. officials seemed to have realized that an at least partial normalization of U.S.-Iranian relations is a precondition for further, much-needed talks of mutual concern in the region, especially in a process where the U.S. can no longer function as the only orderdefining power in the Middle East. In a process of hegemonic decline, it is time for paradigm shifts on geopolitical thinking that will also entail a re-thinking of stigmatized enemy perceptions. These will be no less revolutionary than the historic traumas in U.S.-Iranian relations that culminated in events in the wake of Iran's Islamic Revolution in 1979, resulting in the break-off of diplomatic relations and decades of 'institutionalized enmity', ${ }^{47}$ The possibility of a shift in regional working relationships is what troubles 'traditional' U.S. allies in the region like Saudi Arabia and Israel. Riyadh fears an implicit recognition of Iran's regional power standing that will tilt the balancing act between Riyadh and Tehran over predominance in the Gulf region in Tehran's favor.

A solution of Iran's nuclear crisis and the efforts to repair U.S.-Iranian relations, however, is a condition for consultations with Tehran on the future of Syria, as the Syrian-Iranian alliance

\footnotetext{
${ }^{44}$ Russian Foreign Ministry, Concept of the Foreign Policy of the Russian Federation, 2013. Available at http://www.mid.ru/bdomp/nsosndoc.nsf/1e5f0de28fe77fdcc32575d900298676/869c9d2b87ad8014c32575d9002b1c38! OpenDocument.

${ }^{45}$ Reuters, "Ban Ki-moon withdraws Iran's invite to Syria talks," Reuters, 20 January 2014. Available at: http://www.reuters.com/article/2014/01/20/us-syria-crisis-iran-idUSBREA0J1F720140120. The official justification was that Iran had not endorsed the Geneva Communiqué of 30 June 2013 as a basis for Geneva-II talks.

${ }^{46}$ Yezid Sayigh, "Geneva II: Avoiding a Death Foretold, Part I," Carnegie Endowment for International Peace, Syria in Crisis, 21 January 2014. Available at: http://carnegieendowment.org/syriaincrisis/?fa=54253.

${ }^{47}$ Trita Parsi, A Single Roll of the Dice. Obama's Diplomacy with Iran (New Haven and London: Yale University Press, 2012): 240.
}

Field Code Changed

Field Code Changed

Field Code Changed 
and Iran's support for Assad as described above has shown. Iran's nuclear program and the Syrian civil war are interlinked in their significance for a re-drafting of the geopolitical map of the Middle East. Mark Perry therefore speaks of Tehran as a 'center of gravity' in the Syrian conflict that US policy planning must start to recognize as such. ${ }^{48}$ It remains yet to be seen how Tehran will address and embrace the idea of a long-term power transition in Syria away from Assad, ${ }^{49}$ but Iranian initiatives like the four-point plan for Syria indicate a widening base for joint talking points with Iran. ${ }^{50}$ Washington and Tehran share more enemies than both are willing to accept. Iran's fear of the spread of Sunni extremism in the region was almost certainly a major motivation for Rouhani's administration to seek dialogue and engage in conciliatory diplomacy. ${ }^{51}$ Muriel Asseburg and Heiko Wimmen interestingly remark in this context that some sort of rapprochement with Iran might lessen Western insistence on bringing about regime change in Syria if collaboration with Tehran can be achieved, or has the effect of containing the conflict. ${ }^{52}$ Yet, it remains to be seen to what extent Rouhani wants or is able to change Iran's Syria policy. The basic strategic guidelines are formulated by Supreme Leader Ayatollah Khamenei, and tellingly, it is to the latter that the commander of the al-Quds brigades, Qasim Sulaymani, is accountable. Sulaymani and the IRGC are said to be largely responsible for formulating and implementing Iran's Syria policy. ${ }^{53}$

An inclusionary geopolitical thinking, however, takes time to actualize and replace mental templates of routinized conflict patterns. The unprofessional dilatoriness regarding the withdrawal of an already extended invitation to Iran for Geneva-II was but one example, although there seems to have been a degree of confusion about whether Iran would or would not endorse the Geneva II communiqué , set out as a condition for participation. ${ }^{54}$ While the Syrian opposition threatened to withdraw their participation confirmation, should the UN Secretary General not disinvite Iran again, Moscow called Ban Ki-Moon's eventual disinvitation of Iran a 'mistake'. ${ }^{55}$ While Russia publicly called for the inclusion of Iran in the talks, Moscow essentially walks a tightrope between appearing as an averter of war in the chemical weapons episode and as an obstructive veto player in the Security Council, as well as the steadfast ally of a dictatorial regime exerting state terror. While the Syrian war illustrates the power shifts affecting U.S. hegemony, as argued above, Russia's Syria policy cannot but impact on Russia's standing as well: In particular, the apparent convergence of interests between Russia, Iran and Hezbollah is being followed with a watchful eye in Tel Aviv and undoubtedly has an adverse effect on what are traditionally good relations between Russia and Israel. Of course Russia's high poker bets on Assad's political survival will

${ }^{48}$ Intervention at the conference 'The Syrian Crisis: Can Diplomacy Succeed?', organized by the SETA Foundation, Washington D.C., 14 February 2014.

${ }^{49}$ See Mohsen Milani, "Why Tehran Won't Abandon Assad(ism), “ The Washington Quarterly 36, 4 (2013): 79 93.

50 Press TV, "Iran to discuss 4-point Syria plan with Brahimi: Official, " 17 March 2014. Available at: http://www.presstv.ir/detail/2014/03/17/354988/iran-devises-4point-plan-for-syria/.

${ }^{51}$ Walter Posch, "Iran's Interests in the Nuclear Negotiations," SWP Point of View, 6 December 2013. Available at: http://www.swp-berlin.org/en/publications/point-of-view/irans-interests-in-the-nuclear-negotiations.html. 52 Muriel Asseburg and Heiko Wimmen, "Genf II - Chance zur Einhegung des syrischen Bürgerkriegs," SWPAktuell 3, January 2014, 5.

${ }^{53}$ Karim Sadjadpour, "Verlässlicher Verbündeter. Warum Teheran das Assad-Regime auch künftig nicht fallen lassen wird," Internationale Politik, November/December 2013, 47.

${ }^{54}$ While foreign minister Zarif reportedly initially expressed agreement with the communiqué, other power centers of the central government in Tehran did not.

${ }^{55}$ Reuters, "Russia says Iran's absence from Syria talks is a mistake, not a catastrophe," Reuters, 21 January 2014. Available at: http://www.reuters.com/article/2014/01/21/us-syria-crisis-russiaidUSBREAOK08120140121. 
negatively affect Russian relations with a Syria post-Assad, and are sure to be viewed with suspicion not only by the other Arab states in the region.

\section{Conclusion}

Syria's civil war has seen an increasing confessionalisation and regionalization of what had started as a civil uprising against Bashar al-Assad's authoritarian rule. Different oppositional groups and warlords with markedly diverging agendas now control their own territories, creating para-statist systems of order and 'ungoverned spaces'. At the same time, arguably, the mushrooming of allegedly new rebel formations is accompanied (and expedited) by foreign media hypes, while some re-labeling may actually be a 'repacking and remarketing' strategy of forces on the ground. ${ }^{56}$ Yet, the de-facto fragmentation of Syria as a state is a very real risk, and this will not only have fatal consequences for Syrian society, but may create a power vacuum in the entire region. In the fourth year since the Syrian uprising, religious extremists have infiltrated and taken over parts of the Syrian opposition, providing a breeding ground for increasing sectarian radicalization. 'Moderate' parts of the opposition have lost fighters to al-Qaida affiliated armed branches like the al-Nusra front, which are more effectively organized and represent a more radical, yet easily discernible ideology. These dynamics render the idea of any 'transitional process' to a pluralistic and multi-party system, let alone of stable local ceasefires ${ }^{57}$ a mere policy illusion, even though UN peace envoy Brahimi expressed guarded optimism following the Geneva-II peace talks in Montreux. The fact that the Syrian foreign minister and representatives of the Syrian opposition, led by SNC chairman Ahmad Asi Al-Jabra, sat at the same table could have been a first step towards confidence-building, but following the hostile and mutually opposing positioning of both parties, it soon became clear that Geneva II would fail. While 'state continuity' and the prevention of the country's disintegration can be said to be shared objectives of Assad and the opposition represented in Geneva, the interpretations of how to achieve this are mutually opposing (creation of a transitional governing body versus an electoral cycle). Assad's announcement to hold presidential election as scheduled in June 2014 may fly in the face of those seeking a genuine national reconciliation. But as much as this is a biting irony after three years of an entire country bleeding out, it equally is a strikingly logical consequence of the inaction of some of his international opponents.

On a regional level, a proxy war is under way over very different perceptions and conceptions not only of Syria's future but, along with it, the construction of regional order between Iran, Saudi Arabia, Turkey and Qatar. Hezbollah's public siding with the Assad regime has exacerbated the confessional dimension of the conflict between Shia and Sunni fighters. Hezbollah is fighting an amalgam of different 'rebel' parts of the Syrian opposition, including al-Qaida-affiliated Sunni extremists. But even within the Sunni camp, differences persist between, inter alia, more moderate variants inspired by the Muslim Brotherhood, fundamentalist Salafism and al-Qaida -inspired militant jihadism.

And while a covert proxy war between Turkey, Saudi Arabia, and Qatar arguably is in progress over the regional 'leadership role' of the Sunni camp, the involvement of Iran and the Iranian-Syrian-Hezbollah connection calls to mind the evocation of an 'Axis of resistance' against Israel and America. The latter, it has been argued, must not be stylized as the sole guiding ideological framework that explains Iran's motives. Beyond revolutionary rhetoric,

${ }^{56}$ Yezid Sayigh, "Is the Armed Rebellion in Syria on the Wane?, Carnegie Endowment for International Peace, 24 April 2014. Available at: http://carnegie-mec.org/2014/04/24/is-armed-rebellion-in-syria-on-wane/h8z6\#.

${ }^{57}$ An example of such a local ceasefire was the humanitarian truce agreed on in mid-February to allow for the evacuation of civilians from besieged Homs. 
Tehran is motivated by the very practical fear of the spread of Sunni extremism in the wider region, which is not in America's interest either.

And it is this nexus, coincidentally, that accounts for the potential for pragmatic consultations between Washington and Tehran on the basis of joint regional interests - provided traumatized bilateral relations are partially repaired. An at least mid-term solution for Iran's nuclear status and a closure of the controversial nuclear file is a precondition for a new inclusionary thinking in Middle Eastern politics. Such a paradigm shift is not only dictated by the geostrategic necessity of including Iran in talks about regional security, but also by a changing zeitgeist in international relations in the second decade of the $21^{\text {st }}$ century: During a process of U.S. hegemonic decline, America will no doubt come to the realization that its ordering role in the Middle East has to be rethought. The U.S.-Russian diplomatic showdown in the late summer of 2013 was illustrative of a gradual re-balancing of international politics and, possibly, of the end of Great Power politics in the Middle East. This is not to be confused with the 'rise of Russia' in the wake of a declining U.S. role. As Russia's persistent support for pro-Assad forces has raised eyebrows not only in Arab states in the region, Syria may become the watershed moment for a re-balancing of the international security architecture. As has been shown in this article, the historic dimension of regional conflict and alliance dynamics that interlink the intricate Iranian nuclear issue and the Syrian civil war will leave its mark on relations between state and non-state actors in the Levant, the Gulf and the wider Middle East, and might usher in a new understanding of 'Great Power' diplomacy. And it buries no less than the concept of an ill-defined 'international community'. 